\title{
Chicken Adenovirus (CELO Virus) Particles Augment Receptor-Mediated DNA Delivery to Mammalian Cells and Yield Exceptional Levels of Stable Transformants
}

\author{
MATT COTTEN, ${ }^{*}$ ERNST WAGNER, KURT ZATLOUKAL, AND MAX L. BIRNSTIEL \\ Research Institute of Molecular Pathology (IMP), Dr. Bohrgasse 7, 1030 Vienna, Austria
}

Received 5 January 1993/Accepted 26 March 1993

\begin{abstract}
Delivery of genes via receptor-mediated endocytosis is severely limited by the poor exit of endocytosed DNA from the endosome. A large enhancement in delivery efficiency has been obtained by including human adenovirus particles in the delivery system. This enhancement is probably a function of the natural adenovirus entry mechanism, which must include passage through or disruption of the endosomal membrane. In an efiort to identify safer virus particles useful in this application, we have tested the chicken adenovirus CELO virus for its ability to augment receptor-mediated gene delivery. We report here that CELO virus possesses pH-dependent, liposome disruption activity similar to that of human adenovirus type 5. Furthermore, the chicken adenovirus can be used to augment receptor-mediated gene delivery to levels comparable to those found for the human adenovirus when it is physically linked to polylysine ligand-condensed DNA particles. The chicken adenovirus has the advantage of being produced inexpensively in embryonated eggs, and the virus is naturally replication defective in mammalian cells, even in the presence of wild-type human adenovirus.
\end{abstract}

We have developed a receptor-mediated gene delivery system $(7,8,44,47)$ which uses the endosomolytic activity of adenovirus particles to enhance entry of DNA into target cells $(9,12,13,43)$. Initial experiments were performed with adenovirus dl312, a replication-defective, E1a-deficient strain of human adenovirus type 5 (Ad5) which can be grown on the E1-complementing cell line $293(16,19)$. The augmentation phenomenon generated by the adenovirus particle relies upon the use of high levels of adenovirus, in the range of 3,000 to 10,000 virus particles per cell (60 to 200 PFU per cell). Although we can observe greater than $90 \%$ transient transfection efficiencies on a variety of cells types, treating cells with this high multiplicity of $d l 312$ particles can generate some toxicity problems. Some of these problems are clearly due to the ability of $d l 312$ to replicate in certain cell types at high multiplicity of infection (19). Toxicity may also result from the expression of various early or late viral genes in the absence of viral replication. Psoralen-UV treatment of adenovirus particles relieves much of the short-term toxicity (9). However, we wondered whether genetic approaches might complement chemical inactivation of virus particles. Therefore, we are testing a variety of other viral particles for their function in our system.

The ideal endosomolytic adenovirus particle would augment gene delivery as well as remain transcriptionally and replicationally inert once it enters the target cell. One approach might involve the use of adenovirus strains from distant species. Members of the adenovirus family have been isolated from birds, amphibians, and a variety of mammals (18). An adenovirus from a distant species might show reduced toxicity in the target cells, as chicken or frog adenoviruses would not be expected to replicate or initiate substantial gene expression in mammalian cells. Viruses from distant species would present a reduced hazard to the investigator and would be less subject to interference by antibodies against human or murine adenovirus when these

\footnotetext{
* Corresponding author.
}

viruses are used in gene therapy experiments in mice and humans. We have chosen to test the chicken adenovirus CELO (chicken embryo lethal orphan) virus, (46) in our DNA delivery system. CELO virus shows no reactivity to antibodies that recognize the major group epitopes of the adenoviruses infecting mammalian cells.

A limit to the use of the chicken virus in mammalian cells may be the entry of the virus into the cell if a receptor for this virus is not present on mammalian cells. This problem can be solved by coupling the chicken virus to DNA-polylysine (pLys) complexes containing a ligand for mammalian cells (e.g., transferrin), a strategy that has been successfully used to carry Ad5-DNA complexes into human blood cells (43).

To test these ideas, CELO virus (avian adenovirus type 1) was tested for its ability to augment DNA delivery into mammalian cells in a fashion analogous to the use of human Ad5. In many cell types, the chicken virus works with efficiencies comparable to those of the human adenovirus. We find, however, that coupling the virus to the cargo DNA is essential for high-efficiency transport, consistent with the idea that the chicken virus alone is not efficiently internalized by these cells. The chicken virus appears to be less toxic than the human Ad5 mutant $d l 312$. This lack of toxicity facilitates the isolation of stable expressing clones at efficiencies of 5 to $10 \%$.

\section{MATERIALS AND METHODS}

CELO virus (Phelps strain, serotype FAV-1; kindly supplied by Gerhard Monreal and Sabine Schüller, Institut für Geflügelkrankheiten, Freie Universität Berlin) was used in these experiments. The initial strain (adapted for cell culture growth) was serially passaged five times in 9-day chicken embryos to enhance viral yields. Approximately $10^{10}$ virus particles in $100 \mu \mathrm{l}$ of $N$-2-hydroxyethylpiperazine- $N^{\prime}-2$ ethanesulfonic acid (HEPES)-buffered saline (HBS; $150 \mathrm{mM}$ $\mathrm{NaCl}, 20 \mathrm{mM}$ HEPES [pH 7.4]) were injected into the allantoic cavity of 8 - to 10 -day chicken embryos. After a 90 -h incubation at $37^{\circ} \mathrm{C}$ in a humidified incubator, the allantoic 
fluid was harvested (approximately $8 \mathrm{ml}$ per egg) and clarified by low-speed centrifugation $(1,000 \times g, 10 \mathrm{~min})$. The clarified supernatant $(25 \mathrm{ml})$ was then layered on top of $10 \mathrm{ml}$ of $1.45-\mathrm{g} / \mathrm{ml} \mathrm{CsCl}$ (in $20 \mathrm{mM}$ HEPES [pH 7.4]) and centrifuged for $1 \mathrm{~h}$ at $25,000 \mathrm{rpm}$. The virus-free supernatant was removed and replaced with a fresh aliquot of the clarified allantoic fluid, and the centrifugation was repeated. This process was repeated two to three times per $\mathrm{CsCl}$ pad. The virus, which accumulates as an opalescent band just below the egg supernatant- $\mathrm{CsCl}$ interface, was collected, the sample was adjusted to a density of $1.34 \mathrm{~g} / \mathrm{ml}$ with $\mathrm{CsCl}$, and the material was centrifuged to equilibrium in a Beckman Vti-65 centrifuge rotor $(63,000 \mathrm{rpm},>4 \mathrm{~h})$. CELO virus bands at an apparent density of $1.35 \mathrm{~g} / \mathrm{ml}$. At least two and often three $\mathrm{CsCl}$ equilibrium centrifugations were required to generate virus of sufficient purity. The final purified virus was used directly for biotinylation.

For biotinylation, the virus $(2 \mathrm{ml}$ in ca. $1.35-\mathrm{g} / \mathrm{ml} \mathrm{CsCl}-20$ mM HEPES [pH 7.4], i.e., virus directly from a $\mathrm{CsCl}$ gradient) was reacted with $20 \mu \mathrm{l}$ of $1 \mathrm{mM}$ NHS-LC-Biotin (Pierce catalog no. 21335, freshly dissolved in $10 \mathrm{mM}$ HEPES [pH 7.9]) for $3 \mathrm{~h}$ at room temperature. The biotinylated virus was then dialyzed four times against $300 \mathrm{ml}$ of HBS $-40 \%$ glycerol at $4^{\circ} \mathrm{C}$ and subsequently stored in aliquots at $-70^{\circ} \mathrm{C}$. Virus quantitation was performed by measuring virus protein and using the conversion factor $1 \mathrm{mg}$ of virus protein $=3.4 \times 10^{12}$ virus particles $(25)$ developed for human adenovirus type 5 studies. The Ela-defective adenovirus dl312 (19) grown in 293 cells (16) was purified and biotinylated as previously described $(9,43)$.

All DNA samples used were purified by double $\mathrm{CsCl}$ purification as described previously (8). Plasmid pCLuc is described in reference 30; plasmid pWeLuc and cosmid CosLuc are described in reference 9; pCMV $\beta$ gal is described in reference 29. The synthesis of human transferrin-pLys (TfpL) was performed as described in reference 41. Streptavidin-pLys (StrpL) conjugate preparation is described in reference 43. Assays for luciferase were performed as described in reference 8 . Briefly, cells to be harvested were washed once with phosphate-buffered saline (PBS) and scraped into a minimum volume of PBS by using a plastic policeman. The cells were then collected by centrifugation, the cell pellet was washed once with PBS, and finally the cells were suspended in $100 \mu \mathrm{l}$ of $200 \mathrm{mM}$ Tris ( $\mathrm{pH} 7.5)$ per $5 \times 10^{5}$ cells. The cells were then disrupted by three freeze-thaw cycles and centrifuged at $15,000 \times g$ for $5 \mathrm{~min}$, and the supernatants, standardized for protein content, were assayed for luciferase activity (8). All experiments were repeated two to three times with similar relative luciferase values within each experiment, although absolute values of luciferase varied between experiments. Staining of cells with 5-bromo-4-chloro-3-indolyl- $\beta$-D-galactopyranoside (X-Gal) for $\beta$-galactosidase activity was carried out as described in reference 28 .

\section{RESULTS}

Adenovirus $d l 312$ and CELO virus display pH-dependent membrane disruption activity. A variety of experiments support the notion that adenovirus enhances receptor-mediated gene delivery by disrupting the endosome in a $\mathrm{pH}$ dependent manner. Human adenovirus has been found to disrupt liposomes in a $\mathrm{pH}$-dependent fashion (5); several of the viral capsid proteins increase their hydrophobicity (as measured by detergent binding) as the $\mathrm{pH}$ is lowered below 5 (36), and adenovirus permeabilizes cell membranes at $\mathrm{pH} 6$
$(34,35)$. We tested the membrane disruption activity of adenoviruses by using a liposome leakage assay in which a lipid membrane encapsidates a high, self-quenching concentration of the fluorescent dye calcein (42). When lesions are generated in the lipid bilayer, the resulting leakage and dilution of the dye result in an increase in the fluorescence of the sample. Therefore, measurement of the fluorescence increase yields an indication of the membrane disruptive activity of a sample. Furthermore, strong correlations between $\mathrm{pH}$-dependent liposome disruption and effective DNA delivery have been found for endosomolytic peptide-pLys conjugates (42). We wanted to compare the $\mathrm{pH}$-dependent liposome disruption activity of CELO virus with that of the human Ad5, which we know augments receptor-mediated gene delivery to a high level $(9,12,13,43)$.

Samples of Ad5 (dl312) and CELO virus were tested for liposome disruption activity as a function of $\mathrm{pH}$. We find that both viruses display time-dependent liposomolytic activity in this assay at $\mathrm{pH} 5.0$, with no liposome leakage generated at pH 7 (Fig. 1A). Human Ad5 maintains approximately 50\% of its $\mathrm{pH} 5$ activity at $\mathrm{pH} 5.5$ and 6.0, dropping to nearbackground levels at $\mathrm{pH} 7$, while CELO virus displays a much sharper increase in liposome disruption going from $\mathrm{pH}$ 5.5 to 5.0 (Fig. 1B). This finding is slightly different from the liposome disruption data obtained by Blumenthal et al. (5) for Ad2, which showed a very apparent optimum at $\mathrm{pH}$ 6.0. CELO virus, while displaying $24 \%$ greater activity than did the human virus at $\mathrm{pH} 5.0$, has less than half of the Ad5 activity at higher pHs.

CELO virus augments DNA delivery in HeLa and $\mathrm{C2C12}$ cells. The TfpL-condensed gene and adenovirus particles were added to cells expressing both the transferrin receptor and the adenovirus receptor. Binding and coendocytosis of both materials can occur. The low $\mathrm{pH}$ of the endosome is thought to allow the adenovirus particle to trigger a membrane disruption (endosomolysis) which allows both the virus and coendocytosed DNA to enter the cytoplasm. Successful gene delivery in this system is measured by the resulting luciferase activity.

We supplied HeLa cells with TfpL-DNA (pCLuc) complexes alone, in the presence of free adenovirus $d l 312$, or in the presence of an equal quantity of CELO virus (Fig. 2A, lines 1 to 3 ). These are conditions similar to those used for the original free adenovirus augmentation of DNA delivery (12). We observe the expected 350-fold augmentation of DNA delivery by $d l 312$ (line 2) as measured by the resulting luciferase activity. However, the optimum quantity of CELO virus, while triggering a modest increase in DNA delivery (approximately 16-fold; compare lines 1 and 3), was 20 -fold less active than the human adenovirus dl312. We suspected that one cause of the poor activity might be inefficient binding and internalization of the chicken virus by human cells.

Previously we found that coupling human adenovirus $d l 312$ to TfpL-DNA complexes is crucial for efficient delivery into blood cells (43), which are deficient in binding and/or internalization of adenovirus $(17,38)$. We concluded that presenting the virus in this context allows efficient internalization via the transferrin receptor. We wondered whether a similar ploy might be used to carry the chicken adenovirus into human cells. Therefore, we prepared biotinylated CELO virus and used a StrpL bridge to attach the virus to TfpL-DNA complexes. These new complexes can enter human cells via the transferrin receptor or via pLys-cell interactions, carrying with them the endosomolytic activity of CELO virus. 

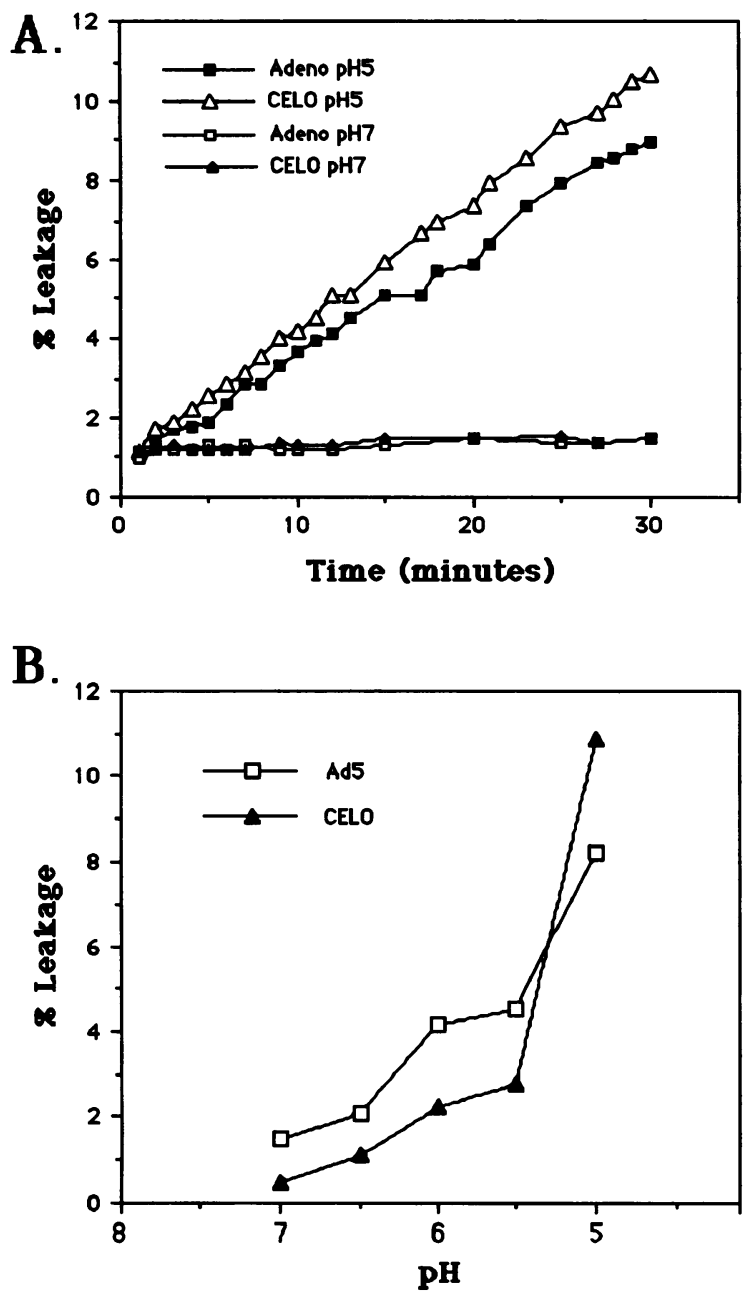

FIG. 1. pH-dependent membrane disruption activities of adenovirus $d l 312$ and CELO virus. (A) CsCl-purified adenovirus or CELO virus ( $3 \mu \mathrm{g}$ of protein) was incubated with $1 \mathrm{ml}$ of $200 \mathrm{mM} \mathrm{NaCl}-20$ $\mathrm{mM}$ sodium citrate ( $\mathrm{pH} 7.0$ or 5.0 ) containing iso-osmolar, calceinloaded liposomes (42). The fluorescence increase (excitation at 495 $\mathrm{nm}$, measurement at $515 \mathrm{~nm}$ ) at the indicated times was measured and expressed as a percentage of the $100 \%$ fluorescence value (obtained by adding $5 \mu \mathrm{l}$ of $10 \%$ Triton X-100 to the sample at the end of the incubation period) after subtracting the background leakage values. Background leakage values were obtained from liposome samples exposed to identical volumes of the virus storage buffer (HBS $-40 \%$ glycerol) incubated over the same time and $\mathrm{pH}$ values. (B) Adenovirus or CELO virus samples were analyzed as in panel A with $1 \mathrm{ml}$ of $200 \mathrm{mM} \mathrm{NaCl}-20 \mathrm{mM}$ sodium citrate (pH 7.0, $6.5,6.0,5.5$, or 5.0 ) containing calcein-loaded liposomes. The fluorescence increase at $\mathbf{3 0} \mathrm{min}$ was measured and expressed as a percentage of the $100 \%$ fluorescence value.

The delivery by human adenovirus is improved only threefold by coupling the DNA to the virus (Fig. 2A, line 5 versus line 2 ), probably because there are sufficiently high levels of human adenovirus and transferrin receptors on these cells to allow coendocytosis of uncoupled virus and TfpL-DNA complexes. When CELO virus is supplied to HeLa cells coupled directly to the TfpL-DNA, we find that the resulting DNA delivery (Fig. 2A, line 6) is greatly increased, so that its activity is comparable to the activity obtained with either the coupled (line 5) or free (line 2) $d l 312$.
A. Hela Light units

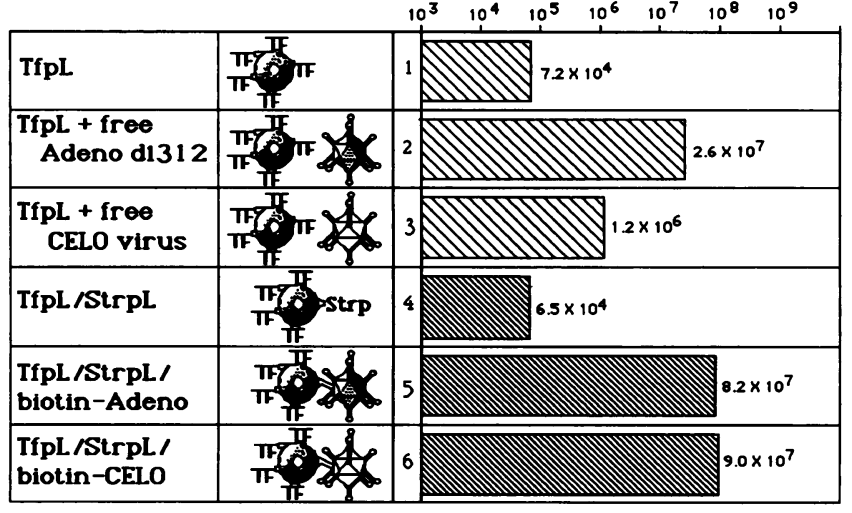

\section{B. $\mathrm{C} 2 \mathrm{C} 12$}

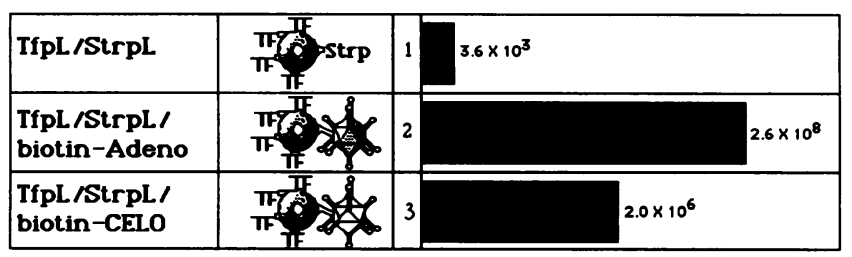

FIG. 2. Augmentation of DNA delivery in HeLa cells by CELO virus. HeLa cells $(\mathrm{A})$ or $\mathrm{C} 2 \mathrm{C} 12$ myoblasts $\left(\mathrm{B} ; 5 \times 10^{5}\right.$ cells per 6-cm-diameter dish) were incubated in $2 \mathrm{ml}$ of Dulbecco modified Eagle medium supplemented with $2 \%$ heat-inactivated fetal calf serum with $6 \mu \mathrm{g}$ of plasmid pCLuc (30) complexed with the indicated pLys or TfpL mixtures in $500 \mu l$ of HBS incubated for 30 min at room temperature. The samples were then added to the cells at $37^{\circ} \mathrm{C}$ in the presence of $18 \mu \mathrm{l}$ of $d l 312\left(10^{12}\right.$ virus particles per ml; sample 2) or $30 \mu \mathrm{l}$ of CELO virus $\left(10^{11}\right.$ virus particles per ml; sample 3 ). With the samples containing biotinylated virus coupled to StrpL-DNA, the same quantities of either biotinylated $d l 312$ (sample 5) or biotinylated CELO virus (sample 6) were preincubated with 1 $\mu \mathrm{g}$ of StrpL in $200 \mu \mathrm{l}$ of HBS for $30 \mathrm{~min}$ at room temperature before addition of $6 \mu \mathrm{g}$ of plasmid pCLuc in $100 \mu \mathrm{l}$ of HBS. After a 30-min room temperature incubation, $7 \mu \mathrm{g}$ of $\mathrm{TfpL}$ (containing $3.5 \mu \mathrm{g}$ of pLys) in $100 \mu \mathrm{l}$ of HBS was added. After a final 30-min room temperature incubation, the material was added to cells at $37^{\circ} \mathrm{C}$. Two hours later, $5 \mathrm{ml}$ of Dulbecco's modified Eagle medium supplemented with $10 \%$ fetal calf serum was added to all cells; $24 \mathrm{~h}$ later, the cells were harvested and processed for the luciferase assay.

Therefore, providing a new internalization route for CELO virus allows it to function with activity comparable to that of the human adenovirus. Note, however, that even in the absence of the StrpL bridge, the CELO virus delivery activity is not zero (Fig. 2, line 1 versus line 3). The major capsid protein of the chicken adenovirus, hexon, is quite acidic, containing nearly $26 \mathrm{~mol} \%$ aspartic and glutamic acid residues (24); as a consequence, intact virus particles can bind to pLys-agarose and are eluted by high salt concentrations (unpublished data). Thus, a stable interaction between pLys in the TfpL-DNA complex and the acidic CELO virus capsid might explain the partial DNA delivery activity seen in the absence of specific CELO virus-DNA complex coupling.

We next tested CELO virus in the $\mathrm{C} 2 \mathrm{C} 12$ myoblast cell line. These cells have been used as a model system for myoblast gene delivery because of their ability to differentiate into long-lasting myotubes $(3,14)$. We have observed that adenovirus-augmented DNA delivery functions well in 


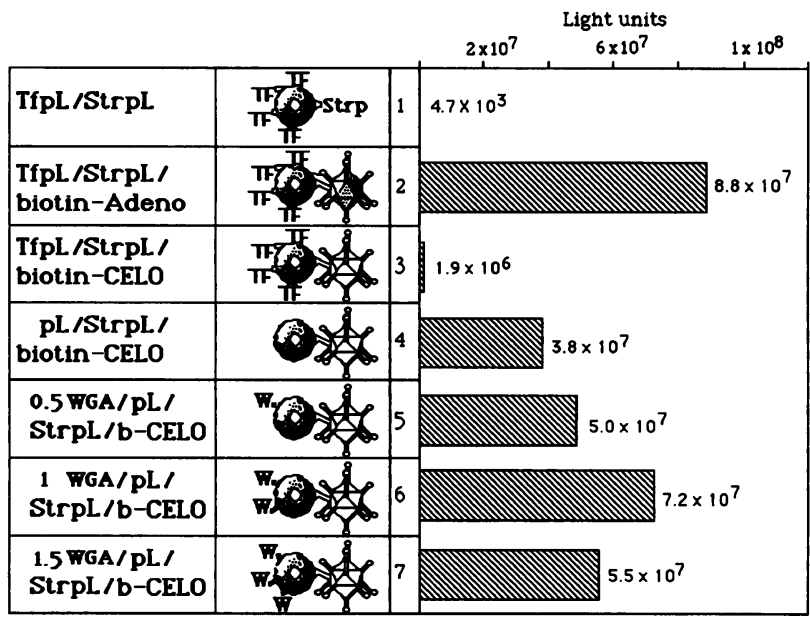

FIG. 3. Improvement of CELO virus DNA delivery in $\mathrm{C} 2 \mathrm{C} 12$ myoblasts by using WGA as a ligand. $\mathrm{C} 2 \mathrm{C} 12$ myoblasts were transfected with $6 \mu \mathrm{g}$ of pCMVL complexed with $1 \mu \mathrm{g}$ of StrpL and $7 \mu \mathrm{g}$ of TfpL alone (sample 1) or plus $5 \mu \mathrm{l}$ of biotinylated adenovirus dl312 ( $10^{12}$ particles per ml; sample 2$)$ or $18 \mu$ l of biotinylated CELO virus $\left(0.3 \times 10^{12}\right.$ particles per $\mathrm{ml}$; sample 3$)$. These complexes were prepared as described for Fig. 2. Samples 4 to 7 , containing $6 \mu \mathrm{g}$ of pCLuc plus StrpL, biotinylated CELO virus, and biotinylated WGA (WGA-B; 2 to $4 \mathrm{~mol}$ of biotin per mol of protein; Boehringer Mannheim), were prepared in the following manner. Virus $(18 \mu \mathrm{l}$, $0.3 \times 10^{12}$ particles per $\mathrm{ml}$ ) and WGA were mixed in $150 \mu \mathrm{l}$ of HBS. StrpL was diluted in $150 \mu$ lof HBS, and the two solutions were mixed and incubated at room temperature for $30 \mathrm{~min}$. The DNA sample (in $100 \mu l$ of HBS) was added to the StrpL-virus-WGA solution and then incubated for another $30 \mathrm{~min}$ at room temperature. Finally, $3.5 \mu \mathrm{g}$ of pLys 300 in $100 \mu \mathrm{l}$ of HBS was added to the mixture, and again the sample was incubated at room temperature for $30 \mathrm{~min}$. The complexes were supplied to $\mathrm{C} 2 \mathrm{C} 12$ myoblasts $(5 \times$ $10^{5}$ cells per $6-\mathrm{cm}$-diameter dish) in $2 \mathrm{ml}$ of Dulbecco's modified Eagle medium plus $2 \%$ fetal calf serum. One hour later, $5 \mathrm{ml}$ of Dulbecco modified Eagle medium plus $10 \%$ fetal calf serum was added to the cells; $20 \mathrm{~h}$ later, the cells were processed for luciferase activity measurement. The activity (light units) in each entire cell sample is displayed.

these cells but only if the adenovirus is coupled directly to the DNA complex. In contrast to the results for HeLa cells, CELO virus is 100 -fold less active than $d l 312$ in myoblasts, even in the TfpL-StrpL-coupled configuration (Fig. 2B, lines 2 and 3). One explanation might be that both the transferrin ligand and the CELO virus ligand are poorly internalized by these cells. We therefore sought a new ligand for the $\mathrm{C} 2 \mathrm{C} 12$ cells.

CELO virus DNA delivery in $\mathrm{C2C12}$ myoblasts is improved by using WGA as a ligand. The lectin wheat germ agglutinin (WGA), which binds $N$-acetylglucosamine residues, is a ligand for muscle cells $(15,22)$. We wondered whether the inclusion of WGA in our CELO virus-DNA complexes might improve binding and subsequent internalization of DNA supplied to $\mathrm{C} 2 \mathrm{C} 12$ cells. Therefore, we prepared either the previously tested StrpL-TfpL-CELO DNA complexes or StrpL-CELO DNA complexes containing increasing amounts of biotinylated WGA and presented these complexes to $\mathrm{C} 2 \mathrm{C} 12$ cells. The TfpL-CELO complexes resulted in the low delivery previously observed (ca. $2 \times 10^{6}$ light units; Fig. 3, line 3), compared with $9 \times 10^{7}$ light units obtained with $d l 312-\mathrm{TfpL}$ complexes (line 2). Merely replacing the $\operatorname{TfpL}$ with unmodified pLys generated a large increase in delivery (line 4 ), probably because pLys bound an as yet unidentified cell surface protein on $\mathrm{C} 2 \mathrm{C} 12$ cells (37). Inclusion of the lectin WGA (in a biotinylated form) in the complexes generated a further twofold increase in delivery (lines 5 and 6). This configuration of CELO virus now allows DNA delivery to $\mathrm{C} 2 \mathrm{C} 12$ cells with efficiencies comparable to that obtained with the human adenovirus (Fig. 3; compare lines 2 and 6). Further increases in WGA content produce complexes that are less efficient, probably because of competition between biotinylated components and StrpL (line 7).

A major improvement in CELO virus activity comes from coupling the virus to pLys-DNA complexes, whereas including transferrin in the CELO virus complex results in much lower activity. This apparent inhibitory activity of the transferrin ligand on CELO virus activity with $\mathrm{C} 2 \mathrm{C} 12$ cells could be a function of the $\mathrm{pH}$ encountered by the virus during internalization. The CELO virus endosomolytic activity displays a sharp increase going from $\mathrm{pH} 5.5$ to 5 , whereas the adenovirus $d l 312$ profile shows much greater activity at the intermediate range ( $\mathrm{pH} 6.0$ to 5.5; Fig. 1). Perhaps the DNA delivery activity of CELO virus requires a low lysosomal $\mathrm{pH}$ $(<6.0)$ that is not obtained with the transferrin-transferrin receptor pair (which cycles down to only $\mathrm{pH} 6.0$ before returning to the surface [6]). Other possible explanations include limited transferrin receptor numbers or recycling on $\mathrm{C} 2 \mathrm{C} 12$ cells or transferrin shielding of the PLys binding effect.

CELO virus augments DNA delivery to levels comparable to those obtained with adenovirus $d l 312$ but displays much less cellular toxicity. One major difficulty with the use of adenovirus $d l 312$ may be the leakiness of the replication defect. Some of the activities of the deleted gene in $d l 312$, E1a, can be compensated by a number of other viral and cellular proteins, including the E7 protein of human papillomavirus expressed in HeLa cells (26). One indication of this phenomenon is the appearance of HeLa cell cultures 48 to $72 \mathrm{~h}$ after a $>90 \%$ efficient, dl312-augmented transfection. The cells are beginning to detach and round up, with the typical features of adenovirus-induced cytopathic effect (Fig. 4C and $\mathrm{D}, d l 312$ versus CELO at $72 \mathrm{~h}$ posttransfection). The extent of this cytopathic effect varies from low in primary, nontransformed cultures to extreme in cultures of primary human tumor cells (e.g., melanoma cells; unpublished data). Therefore, to test the toxicity of CELO virus, we performed a DNA transfection into HeLa cells and compared transfection efficiencies and cytopathic effects 72 to $96 \mathrm{~h}$ posttransfection.

HeLa cells were transfected with expression plasmids (luciferase or LacZ) and either biotinylated $d l 312$ in a TfpLStrpL complex or biotinylated CELO in a StrpL-pLys complex, using optimum virus quantities of 10,000 (dl312) or 3,000 (CELO) virus particles per cell. In parallel, HeLa cells were exposed to a serial dilution series of the optimum virus-DNA complexes. After $72 \mathrm{~h}$, cells were harvested for the luciferase assay (Fig. 4B), stained with crystal violet to determine the number of surviving cells (Fig. 4A), or exposed to $\mathrm{X}-\mathrm{Gal}$ to reveal the $\beta$-galactosidase activity (Fig. 4C).

We find that the two viruses deliver comparable quantities of gene expression as measured by luciferase activity (Fig. 4B) and $\beta$-galactosidase activity (Fig. 4C). However, the $10,000 \mathrm{dl} 312$ virus particles per cell caused cytopathic effects resulting in a loss of approximately 30 to $50 \%$ of the cells (Fig. 4A and C). Threefold-higher levels of $d l 312$ result in complete loss of the cell culture. In contrast, the CELO virus transfection is well tolerated by HeLa cells. Although 3-fold lower quantities of CELO virus relative to $d l 312$ can 
A.
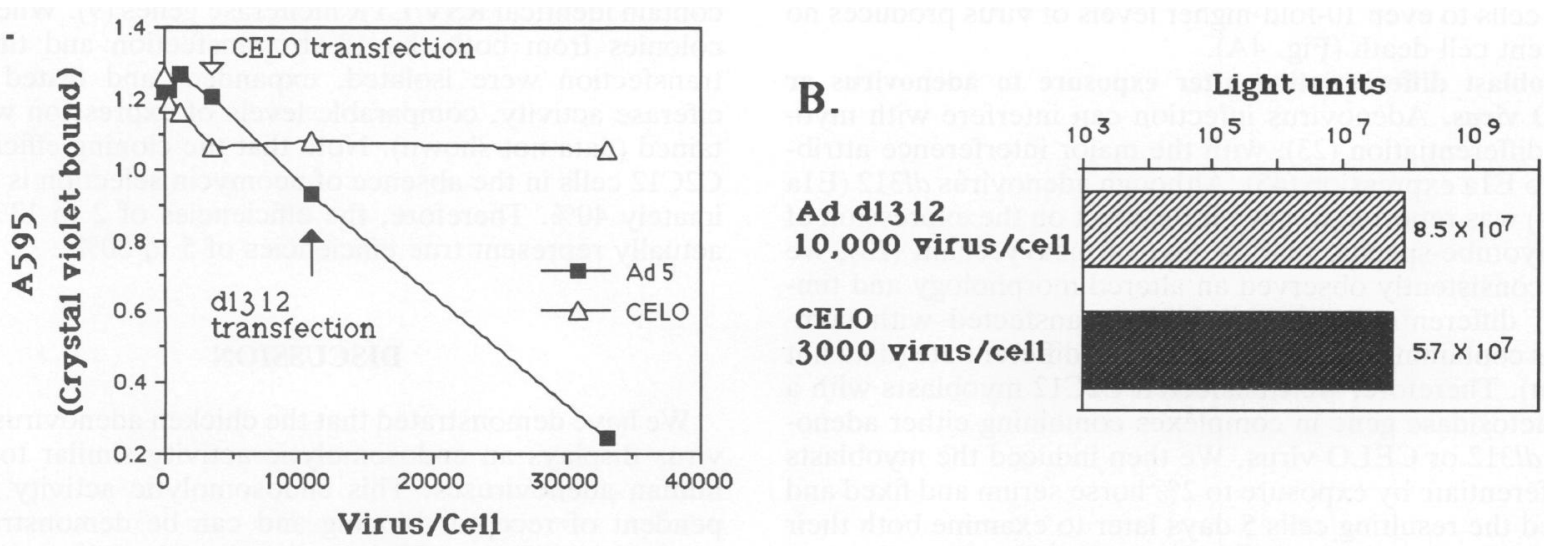

\section{Adenovirus (d1312)}

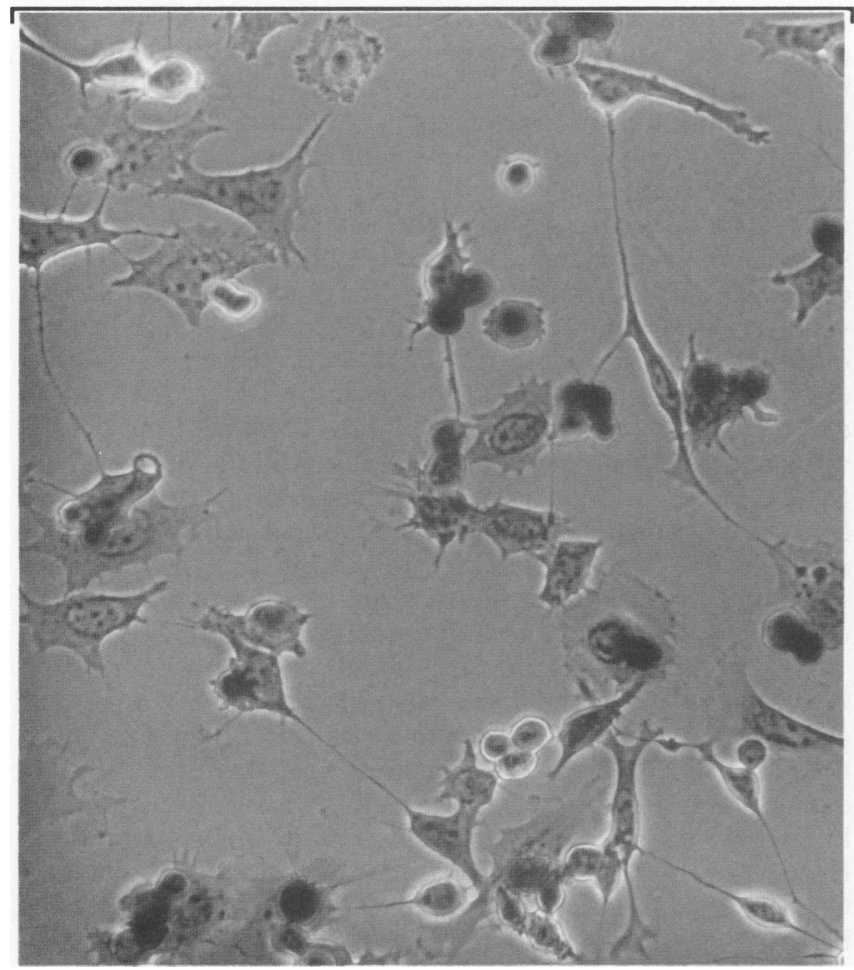

FIG. 4. Evidence that CELO virus augments DNA delivery to levels comparable to those obtained with adenovirus $d l 312$ but displays little cellular toxicity. (A) HeLa cells were plated in a 24 -well dish $\left(5 \times 10^{4}\right.$ cells per well) and $24 \mathrm{~h}$ later placed in Dulbecco's modified Eagle medium plus $2 \%$ fetal calf serum. Aliquots $(660 \mu \mathrm{l})$ of biotinylated CELO virus $\left(3.9 \times 10^{9}\right.$ virus particles $)-1 \mu \mathrm{g}$ of StrpL $-3.5 \mu \mathrm{g}$ of pLys-6 $\mu \mathrm{g}$ of pCLuc, biotinylated adenovirus $d l 312\left(3.2 \times 10^{9}\right.$ virus particles)-7 $\mu \mathrm{g}$ of TfpL-1 $\mu \mathrm{g}$ of StrpL-6 $\mu \mathrm{g}$ of pCLuc, or 3-fold serial dilutions (in HBS) of these complexes were then added to each well. After a 2-h incubation at $37^{\circ} \mathrm{C}$, the medium was removed and replaced with $2 \mathrm{ml}$ of Dulbecco's modified Eagle medium plus $10 \%$ fetal calf serum. After $72 \mathrm{~h}$, the medium was removed, and the cell layer was fixed for 5 min with $4 \%$ formaldehyde- $150 \mathrm{mM} \mathrm{NaCl}$ and then stained for 10 min with $0.1 \%$ crystal violet in $2 \%$ ethanol. The staining solution was then removed, and the well was washed twice with PBS. The bound crystal violet was solubilized in $500 \mu l$ of $96 \%$ ethanol, and the well was washed with an additional $100 \mu \mathrm{l}$ of $96 \%$ ethanol, which was added to the first wash. The crystal violet was quantitated by measuring the $A_{595}$. (B) Virus-DNA complexes as described for panel A were supplied to $5 \times 10^{5} \mathrm{HeLa}$ cells in 6-cm-diameter dishes containing $1 \mathrm{ml}$ of Dulbecco modified Eagle medium plus $2 \%$ fetal calf serum. After $2 \mathrm{~h}$, the medium was replaced with $5 \mathrm{ml}$ of Dulbecco's modified Eagle medium plus $10 \%$ fetal calf serum; $72 \mathrm{~h}$ later, the cells were harvested and assayed for luciferase activity. (C and D) Virus-DNA complexes as described for panel A (containing $6 \mu \mathrm{g}$ of pCMVBgal [29]) were supplied to $5 \times 10^{5} \mathrm{HeLa}$ cells in 6-cm-diameter dishes containing $1 \mathrm{ml}$ of Dulbecco modified Eagle medium plus $2 \%$ fetal calf serum. After $2 \mathrm{~h}$, the medium was replaced with 5 ml of Dulbecco's modified Eagle medium plus $10 \%$ fetal calf serum; $72 \mathrm{~h}$ later, the cells were fixed and stained for $\beta$-galactosidase activity. (C) Cells transfected with adenovirus $d l 312$ complexes; (D) cells transfected with CELO virus complexes. 
be used to generate similar expression levels, exposure of these cells to even 10 -fold-higher levels of virus produces no apparent cell death (Fig. 4A).

Myoblast differentiation after exposure to adenovirus or CELO virus. Adenovirus infection can interfere with myoblast differentiation (23), with the major interference attributed to E1a expression (45). Although adenovirus $d l 312$ (E1a minus) was reported to have little effect on the expression of the myotube-specific marker myosin heavy chain (23), we have consistently observed an altered morphology and timing of differentiation in myoblasts transfected with complexes containing $d l 312$ and induced to differentiate (data not shown). Therefore, we transfected $\mathrm{C} 2 \mathrm{C} 12$ myoblasts with a $\beta$-galactosidase gene in complexes containing either adenovirus $d l 312$ or CELO virus. We then induced the myoblasts to differentiate by exposure to $2 \%$ horse serum and fixed and stained the resulting cells 5 days later to examine both their morphology and the level of gene expression (Fig. 5).

We find similar levels of $\beta$-galactosidase activity for the two viruses. However, compared with the $d l 312$ sample, the resulting myotubes are much larger in the CELO virustreated sample and approach the sizes obtained with nontransfected, differentiated cultures. The ability of CELO virus-transfected myoblasts to form apparently normal myotube structures will have important consequences as we attempt to integrate transfected myoblasts into existing muscle structures in vivo.

Long-term, stable expression of genes delivered with the aid of CELO virus. Although the efficiency of transient gene expression obtained with the human adenovirus is greater than $90 \%$ in many cell types, we have had great difficulty selecting stable expressing cell clones after treatment with the levels of adenovirus $d l 312$ required for this high-level expression (unpublished results). The limited toxicity of CELO virus (Fig. 4 and 5) led us to attempt long-term gene expression studies with CELO virus.

We introduced plasmids containing a neomycin phosphotransferase (neo) gene into HeLa or $\mathrm{C} 2 \mathrm{C} 12$ cells by using TfpL alone or in complexes with adenovirus $d l 312$ or as pLys complexes with CELO virus. The virus and DNA complex conditions used were those optimized for each virus for transient (24- to 48-h) luciferase expression. At $48 \mathrm{~h}$ posttransfection, cells were trypsinized and placed at various dilutions in medium containing G418 at $200 \mu \mathrm{g} / \mathrm{ml}$ (HeLa) or $400 \mu \mathrm{g} / \mathrm{ml}(\mathrm{C} 2 \mathrm{C} 12)$. After 14 days selection, the resulting neomycin-resistant colonies (with greater than 300 cells) were quantitated by crystal violet staining.

With HeLa cells, no stable clones were obtained with the adenovirus complexes. This finding is consistent with the appearance of the cells after $72 \mathrm{~h}$; nearly all cells had detached and were rounded, with the appearance of virus replication. No clones were obtained when cells were treated with TfpL complexes alone, consistent with the low level of transient gene expression obtained with this treatment (Fig. 1 to 4). However, the CELO virus transfections produced neomycin-resistant colonies at a rate of up to ca. 16\% (i.e., 16 colonies per 100 transfected cells plated; Fig. 6).

Similar experiments were performed with $\mathrm{C} 2 \mathrm{C} 12$ cells. In addition, the efficiencies of stable delivery of small plasmids ( 5 or $12 \mathrm{~kb}$ ) versus a cosmid $(48 \mathrm{~kb}$ ) containing the same neo gene were compared. The $\mathrm{C} 2 \mathrm{C} 12$ cells transfected with CELO virus complexes containing small plasmids gave rise to stable expressing clones at efficiencies of 2 to $13 \%$ (Fig. 6). Of considerable interest is the ability to generate clones with the $48-\mathrm{kb}$ cosmid with no reduced frequencies relative to the smaller DNA molecules. Both the 12- and 48-kb molecules contain identical RSV/LTR luciferase genes (9). When single colonies from both the $12-\mathrm{kb}$ transfection and the $48-\mathrm{kb}$ transfection were isolated, expanded, and tested for luciferase activity, comparable levels of expression were obtained (data not shown). Note that the cloning efficiency of $\mathrm{C} 2 \mathrm{C} 12$ cells in the absence of neomycin selection is approximately $40 \%$. Therefore, the efficiencies of 2 to $13 \%$ might actually represent true efficiencies of 5 to $30 \%$.

\section{DISCUSSION}

We have demonstrated that the chicken adenovirus CELO virus displays an endosomolytic activity similar to that of human adenoviruses. This endosomolytic activity is independent of receptor binding and can be demonstrated directly by measuring pH-dependent liposome disruption (Fig. 1). CELO virus can be used to augment receptor-mediated gene delivery analogously to use of the human adenoviruses, with several advantages. Mammalian cells treated with the chicken virus do not show the long-term (48- to 72-h) cytopathic effects often displayed by cells treated with high levels of adenovirus $d / 312$. This lack of cytotoxicity facilitates gene expression experiments not allowed by the human adenovirus. One difference between the two types of viruses is their capacity to bind and be internalized by mammalian cells. The subgroup $\mathrm{C}$ adenovirus receptor is fairly widespread on mammalian cell types, with a lowered binding observed only with blood cells $(17,38)$. Our use of CELO virus to augment receptor-mediated gene transfer has required techniques that introduce new cell-binding ligands on the virus-DNA complex. In the end, however, the lack of endogenous mammalian cell binding capacity on CELO virus may facilitate specific cell targeting applications, using, for example, cell-specific ligands such as a tetragalactose ligand for liver-specific targeting (30) or cell-specific antibodies. Because of the broad distribution of the type $C$ adenovirus receptor, this type of cell targeting is not possible with use of complexes that contain human Ad5 strains.

We are aware that CELO virus, although replication incompetent in mammalian cells $(20,27,33)$, is capable of generating tumors in newborn hamsters after long incubation times $(1,20,33)$. We are monitoring this transforming capacity carefully and have thus far seen no evidence of human or mouse cell transformation in our experiments. However, the baby hamster tumor production capacity of CELO virus is completely blocked by exposing the virus briefly to UV light (20). Therefore, one solution may involve extending the psoralen-UV inactivation strategy that has functioned with human adenovirus particles (9) to CELO virus. Another approach may involve the generation of transformation-defective mutants or the use of chicken adenoviruses that are not implicated in disease $(10,11)$.

The currently used E1-defective recombinant adenoviruses being considered for gene therapy applications $(2,4$, $21,31,32,39,40$; see reference 4 for a review) are certainly replication defective in cell culture in the appropriate cell types. However, in a mixed population of recombinant adenovirus and wild-type adenovirus, the defective recombinant is complemented by the wild type. Depending on the new gene carried by the recombinant virus, this may pose a problem for use of these viruses in human patients, in whom the absence of wild-type adenovirus cannot be ensured. In contrast, the chicken adenovirus is completely replication defective in human cells even in the presence of wild-type 
A

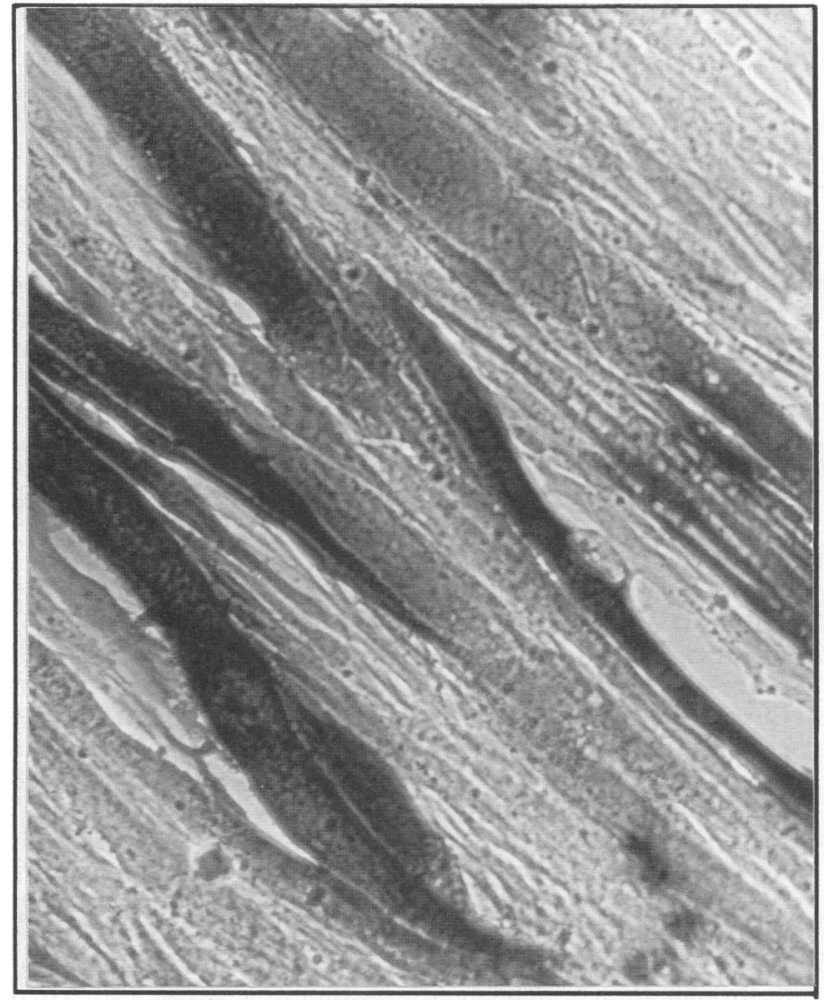

C

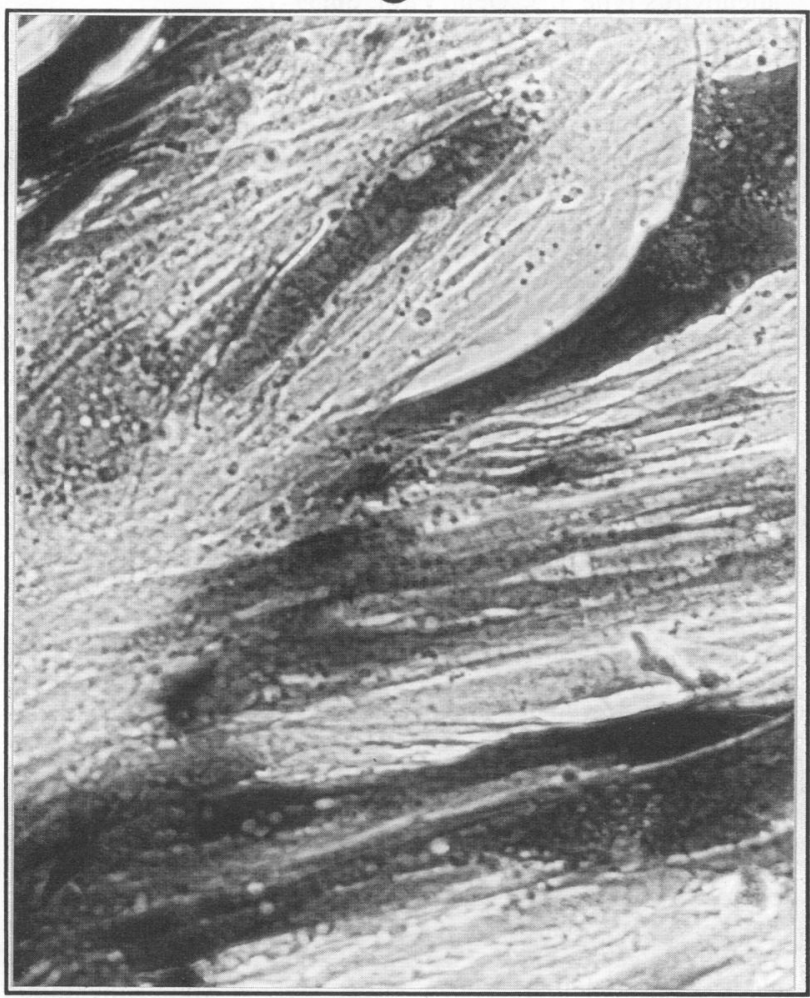

B

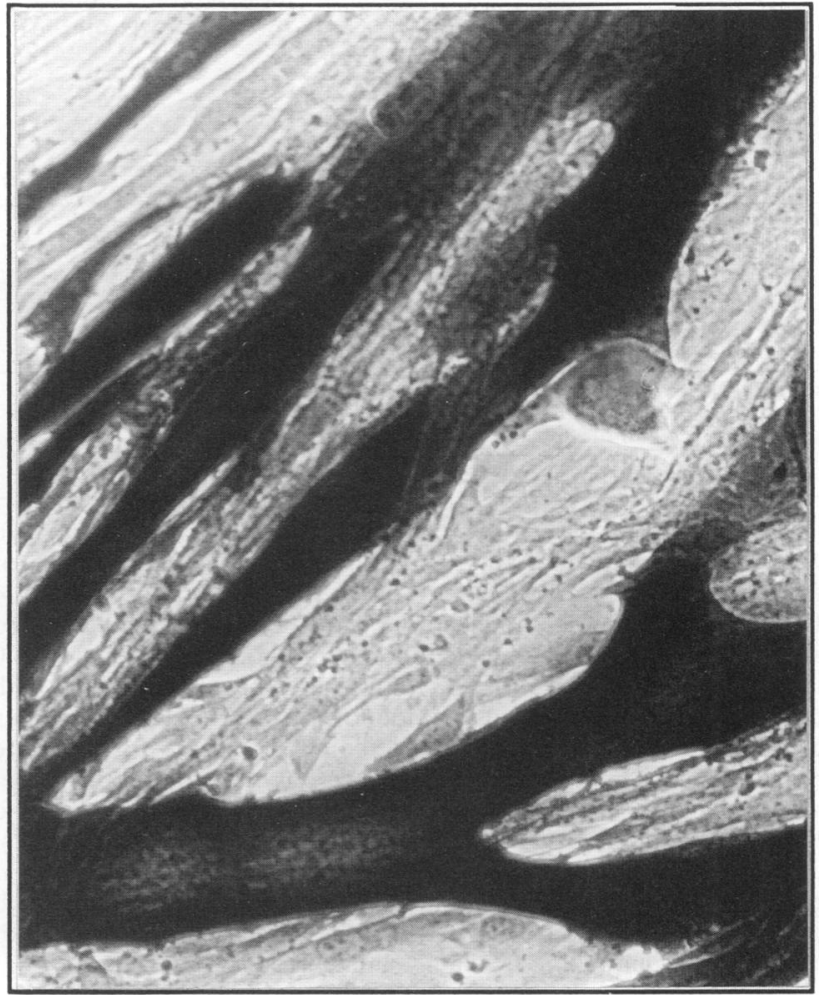

D

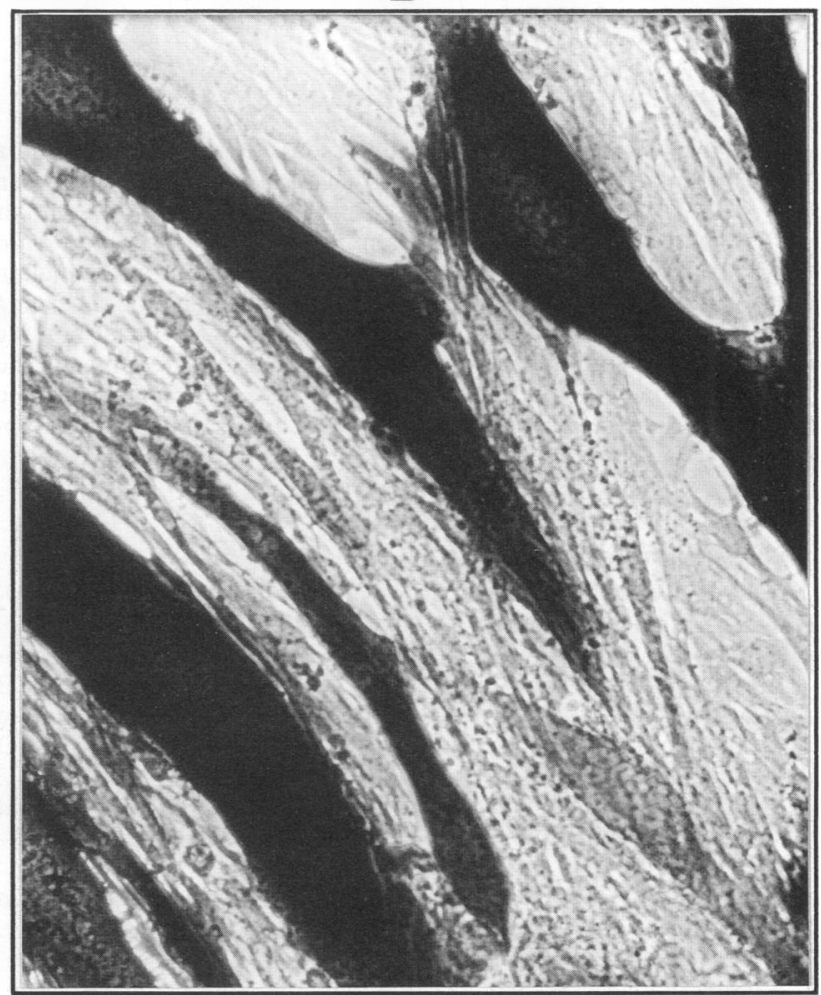

FIG. 5. Myoblast differentiation after exposure to CELO or $d l d 1312$. Samples of $5 \times 10^{5} \mathrm{C} 2 \mathrm{C} 12$ myoblasts (in 6-cm-diameter dishes) were transfected with pCMVBgal DNA in complexes containing either CELO virus plus WGA or dl312 as described for Fig. 3B. At 24 h posttransfection, the medium was changed to $2 \%$ horse serum containing Dulbecco's modified Eagle medium to induce myoblast fusion and differentiation. After 5 days, the cells were fixed and stained for $\beta$-galactosidase activity. (A and C) Cells transfected with adenovirus $d l 312$ complexes; (B and D) cells transfected with CELO virus complexes. 


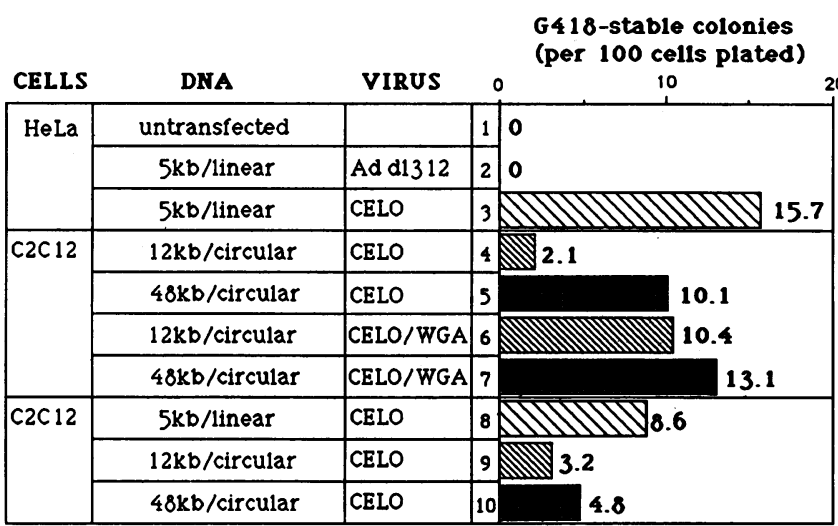

FIG. 6. G418-stable colony formation. Cells were transfected with the optimum conditions for HeLa cells (Fig. 2A, sample 6) or for $\mathrm{C} 2 \mathrm{C} 12$ cells (Fig. 3, samples 4 or 6 ), using $6 \mu \mathrm{g}$ of DNA per $5 \times$ $10^{5}$ cells. At $48 \mathrm{~h}$ after transfection, the cells were trypsinized and aliquots were replated in selection medium containing G418 at 200 $\mu \mathrm{g} / \mathrm{ml}(\mathrm{HeLa})$ or $400 \mu \mathrm{g} / \mathrm{ml}(\mathrm{C} 2 \mathrm{C} 12)$. The dishes were stained with crystal violet at 14 days after initiation of selection, and colonies containing more than 300 cells were scored. The values reported are the frequency of colony appearance per 100 cells plated and represent the averages of four independent transfections. The 12- and 48-kb DNA samples used were pWeLuc ( $12 \mathrm{~kb})$ and CosLuc ( $48 \mathrm{~kb})$, described previously (9). These DNA molecules contain the neo gene under the control of a simian virus 40 promoter. The $5-\mathrm{kb}$ plasmid used is a 5-kb AatI fragment used to generate the 12-kb pWeLuc (9), containing the same simian virus 40 neo gene.

human adenovirus sequences (27). This may be a useful safety feature of CELO virus.

\section{ACKNOWLEDGMENTS}

We thank Christian Scholtissek (Giessen) for helping us locate a chicken adenovirus and for useful advice on virus culture in chicken embryos. We also thank Gerhard Monreal and Sabine Schüller (Berlin) for supplying the initial sample of CELO virus and Mijo Dezic, Hartmut Beug, and Martin Zenke for assistance with chicken embryos. We thank George Dickson (London) for help concerning myoblast culture and differentiation and the use of myoblast-binding lectins. We are grateful to Lisa Ballou for careful reading of the manuscript, and we acknowledge the extensive technical assistance of Mediyha Saltik, Joydeep Basu, Karl Mechtler, and Helen Kirlappos.

\section{REFERENCES}

1. Akopian, T., V. Kruglyak, M. Rivkina, B. Naroditsky, and T. Tikhonenko. 1990. Sequence of an avian adenovirus (CELO) DNA fragment (0-11.2\%). Nucleic Acids Res. 18:2825.

2. Ballay, A., M. Levrero, M. Buendia, P. Tiollais, and M. Perricaudet. 1985. In vitro and in vivo synthesis of the hepatitis B virus surface antigen and of the receptor for polymerized human serum albumin from recombinant human adenoviruses. EMBO J. 4:3861-3865.

3. Barr, E., and J. Leiden. 1991. Systemic delivery of recombinant proteins by genetically modified myoblasts. Science 254:15071509.

4. Berkner, K. L. 1992. Expression of heterologous sequences in adenoviral vectors: review of recombinant adenoviruses. Curr. Top. Microbiol. Immunol. 158:39-66.

5. Blumenthal, R., P. Seth, M. Willingham, and I. Pastan. 1986. pH-dependent lysis of liposomes by adenovirus. Biochemistry 25:2231-2237.

6. Corley Cain, C., D. Sipe, and R. Murphy. 1989. Regulation of endocytic $\mathrm{pH}$ by the $\mathrm{Na}^{+}, \mathrm{K}^{+}$-ATPase in living cells. Proc. Natl. Acad. Sci. USA 86:544-548.
7. Cotten, M., F. Längle-Rouault, H. Kirlappos, E. Wagner, K. Mechtler, M. Zenke, H. Beug, and M. L. Birnstiel. 1990. Transferrin-polycation-mediated introduction of DNA into human leukemic cells: stimulation by agents that affect the survival of transfected DNA or modulate transferrin receptor levels. Proc. Natl. Acad. Sci. USA 87:4033-4037.

8. Cotten, M., E. Wagner, and M. L. Birnstiel. 1993. Receptormediated transport of DNA into eukaryotic cells. Methods Enzymol. 217:618-644.

9. Cotten, M., E. Wagner, K. Zatloukal, S. Phillips, D. Curiel, and M. L. Birnstiel. 1992. High-efficiency receptor-mediated delivery of small and large $(48 \mathrm{~kb})$ gene constructs using the endosome-disruption activity of defective or chemically-inactivated adenovirus particles. Proc. Natl. Acad. Sci. USA 89: 6094-6098.

10. Cowen, B., B. Calnek, N. Menendez, and R. Ball. 1978. Avian adenoviruses: effect on egg production, shell quality and feed consumption. Avian Dis. 22:459-470.

11. Cowen, B. S. 1988. Chicken embryo propagation of type I avian adenoviruses. Avian Dis. 32:347-352.

12. Curiel, D. T., S. Agarwal, E. Wagner, and M. Cotten. 1991. Adenovirus enhancement of transferrin-polylysine mediated gene delivery. Proc. Natl. Acad. Sci. USA 88:8850-8854.

13. Curiel, D., E. Wagner, M. Cotten, M. L. Birnstiel, C. Li, S. Loechel, S. Agarwal, and P. Hu. 1992. High efficiency gene transfer mediated by adenovirus coupled to DNA polylysine complexes via an antibody bridge. Hum. Gene Ther. 3:147-154.

14. Dhawan, J., L. Pan, G. Pavlath, M. Travis, A. Lanctot, and H. Blau. 1991. Systemic delivery of human growth hormone by injection of genetically engineered myoblasts. Science 254: 1509-1512.

15. Ervasti, J., S. Kahl, and K. Campbell. 1991. Purification of dystrophin from skeletal muscle. J. Biol. Chem. 266:9161-9165.

16. Graham, F., J. Smiley, W. Russell, and R. Nairn. 1977. Characteristics of a human cell line transformed by DNA from human adenovirus type 5. J. Gen. Virol. 36:59-72.

17. Horvath, J., and J. Weber. 1988. Nonpermissivity of human peripheral blood lymphocytes to adenovirus type 2 infection. J. Virol. 62:341-345.

18. Horwitz, M. S. 1990. Adenoviridae and their replication, p. 1679-1721. In B. N. Fields, D. M. Knipe, R. M. Chanock, M. S. Hirsch, J. L. Melnick, T. P. Monath, and B. Roizman (ed.), Virology. Raven Press Ltd., New York.

19. Jones, N., and T. Shenk. 1979. An adenovirus type 5 early gene function regulates expression of other early viral genes. Proc. Natl. Acad. Sci. USA 76:3665-3669.

20. Jones, R., B. Asch, and D. Yohn. 1970. On the oncogenic properties of chicken embryo lethal orphan virus, an avian adenovirus. Cancer Res. 30:1580-1585.

21. Karlsson, S., R. Humphries, Y. Gluzman, and A. Nienhuis. 1985. Transfer of genes into hematopoietic cells using recombinant DNA viruses. Proc. Natl. Acad. Sci. USA 82:158-162.

22. Kirkeby, S., T. Bog-Hansen, D. Moe, and C. Garbarsch. 1991. Lectin binding in skeletal muscle. Evaluation of alkaline phosphatase conjugated avidin staining procedures. Histochem. $\mathbf{J}$. 23:345-354.

23. Kohtz, D. S., F. Cole, M. Wong, and M. Hsu. 1991. Infection and inhibition of differentiation of human fetal skeletal myoblasts by adenovirus. Virology 184:569-579.

24. Laver, W. G., H. B. Younghusband, and N. G. Wrigley. 1971. Purification and properties of chick embryo lethal orphan virus (an avian adenovirus). Virology 45:598-614.

25. Lemay, P., M. Boudin, M. Milleville, and P. Boulanger. 1980. Human adenovirus type 2 protein IIIa. I. Purification and characterization. Virology 101:131-143.

26. Levine, A. J. Viruses. W. H. Freeman \& Co., New York.

27. Li, P., A. Bellett, and C. Parish. 1984. DNA-binding proteins of chick embryo lethal orphan virus: lack of complementation between early proteins of avian and human adenoviruses. J. Gen. Virol. 65:1817-1825.

28. Lim, K., and C. Chae. 1989. A simple assay for DNA transfection by incubation of the cells in culture dishes with substrates for $\beta$-galactosidase. BioTechniques 7:576-579. 
29. MacGregor, G., and C. T. Caskey. 1989. Construction of plasmids that express $E$. coli $\beta$-galactosidase in mammalian cells. Nucleic Acids Res. 17:2365.

30. Plank, C., K. Zatloukal, M. Cotten, K. Mechtler, and E. Wagner. 1992. Gene transfer into hepatocytes using asialoglycoprotein receptor mediated endocytosis of DNA complexed with an artificial tetra-antennary galactose ligand. Bioconjugate Chem. 3:533-539.

31. Quantin, B., L. Perricaudet, S. Tajbakhsh, and J. Mandel. 1992. Adenovirus as an expression vector in muscle cells in vivo. Proc. Natl. Acad. Sci. USA 89:2581-2584.

32. Rosenfeld, M., K. Yoshimura, B. Trapnell, K. Yoneyama, E. Rosenthal, W. Dalemans, M. Fukayama, J. Bargon, L. Stier, L. Stratford-Perricaudet, M. Perricaudet, W. Guggino, A. Pavirani, J. Lecocq, and R. G. Crystal. 1992. In vivo transfer of the human cystic fibrosis transmembrane conductance regulator gene to the airway epithelium. Cell 68:143-155.

33. Sarma, P., R. Huebner, and W. Lane. 1965. Induction of tumors in hamsters with an avian adenovirus (CELO). Science 149: 1108.

34. Seth, P., I. Pastan, and M. Willingham. 1985. Adenovirusdependent increase in cell membrane permeability. J. Biol. Chem. 260:9598-9602.

35. Seth, P., M. Willingham, and I. Pastan. 1984. Adenovirusdependent release of ${ }^{51} \mathrm{Cr}$ from $\mathrm{KB}$ cells at an acidic $\mathrm{pH}$. J. Biol. Chem. 259:14350-14353.

36. Seth, P., M. Willingham, and I. Pastan. 1985. Binding of adenovirus and its external proteins to Triton X-114. J. Biol. Chem. 260:14431-14434.

37. Shen, W., and H. J. P. Ryser. 1978. Conjugation of poly-L-lysine to albumin and horseradish peroxidase: a novel method of enhancing the cellular upake of proteins. Proc. Natl. Acad. Sci. USA 75:1872-1876.

38. Silver, L., and C. Anderson. 1988. Interaction of human adenovirus serotype 2 with human lymphoid cells. Virology 165:377387.
39. Stratford-Perricaudet, L., M. Levrero, J. Chasse, M. Perricaudet, and P. Briand. 1990. Evaluation of the transfer and expression in mice of an enzyme-encoding gene using a human adenovirus vector. Hum. Gene Ther. 1:241-256.

40. Stratford-Perricaudet, L., I. Makeh, M. Perricaudet, and P. Briand. 1992. Widespread long-term gene transfer to mouse skeletal muscles and heart. J. Clin. Invest. 90:626-630.

41. Wagner, E., M. Cotten, K. Mechtler, H. Kirlappos, and M. L. Birnstiel. 1991. DNA-binding transferrin conjugates as functional gene-delivery agents: synthesis by linkage of polylysine or ethidium homodimer to the transferrin carbohydrate moiety. Bioconjugate Chem. 2:226-231.

42. Wagner, E., C. Plank, K. Zatloukal, M. Cotten, and M. L. Birnstiel. 1992. Influenza virus hemagglutinin HA-2 N-terminal fusogenic peptides augment gene transfer by transferrin-polylysine-DNA complexes: toward a synthetic virus-like genetransfer vehicle. Proc. Natl. Acad. Sci. USA 89:7934-7938.

43. Wagner, E., K. Zatloukal, M. Cotten, H. Kirlappos, K. Mechtler, D. Curiel, and M. L. Birnstiel. 1992. Coupling of adenovirus to transferrin-polylysine/DNA complexes greatly enhances receptor-mediated gene delivery and expression of transfected cells. Proc. Natl. Acad. Sci. USA 89:6099-6103.

44. Wagner, E., M. Zenke, M. Cotten, H. Beug, and M. L. Birnstiel. 1990. Transferrin-polycation conjugates as carriers for DNA uptake into cells. Proc. Natl. Acad. Sci. USA 87:3410-3414.

45. Webster, K., G. Muscat, and L. Kedes. 1988. Adenovirus E1a products suppress myogenic differentiation and inhibit transcription from muscle-specific promoter. Nature (London) 332: 553-557.

46. Yates, V., and D. Fry. 1957. Observations on a chicken embryo lethal orphan (CELO) virus. Am. J. Vet. Res. 18:657-660.

47. Zenke, M., P. Steinlein, E. Wagner, M. Cotten, H. Beug, and M. L. Birnstiel. 1990. Receptor-mediated endocytosis of transferrin polycation conjugates: an efficient way to introduce DNA into hematopoietic cells. Proc. Natl. Acad. Sci. USA 87:36553659. 